\title{
DESPAIR AS A GOVERNING STRATEGY: AUSTRALIA AND THE OFFSHORE PROCESSING OF ASYLUM SEEKERS ON NAURU
}

\author{
Caroline Fleay and Sue Hoffman*
}

\begin{abstract}
As part of its efforts to deter the arrival of asylum seekers by boat to Australia in 2001, Prime Minister John Howard's Coalition government established the offshore processing of refugee claims. Known as the Pacific Solution, this policy included an agreement with Nauru and Papua New Guinea's Manus Island for asylum seekers arriving to Australia by boat to be transported to either of these islands where they would wait in camps while their refugee claims were processed. The majority of the asylum seekers subjected to offshore processing at this time were held on Nauru, and most had fled Afghanistan. Governmentality, as introduced by Michel Foucault and developed by later scholars, provides insight into the institutions, methods, techniques, strategies and tactics mechanisms used by governments to achieve its ends. This paper explores Australian government policy and the experience of Afghan asylum seekers held on Nauru from 2001 using a governmentality approach. Given that people seeking asylum in Australia are once again being transported to Nauru and Papua New Guinea, this time under a Labor government, this paper's findings are pertinent for insight into understanding current Australian policy.
\end{abstract}

Keywords: offshore processing, asylum seekers, Nauru, Australia

\footnotetext{
* Caroline Fleay is Lecturer at the Centre for Human Rights Education, Curtin University. Sue Hoffman is an Honorary Research Associate at Murdoch University, Perth WA
} 


\section{Introduction}

As we write this paper, the Australian media is dominated by stories about the Labor government's intention to expand its offshore processing policy for asylum seekers. This includes an announcement that from 19 July 2013 any asylum seekers who arrive to Australia by boat will be transported to Papua New Guinea where their refugee claims will be processed and where they will be resettled should they be found to be refugees. ${ }^{1}$ These asylum seekers will add to the more than 700 who have already been detained on Nauru and Papua New Guinea's Manus Island since September 2012 as part of the Labor government's efforts to deter the arrival of further asylum seekers by boat. In the wake of the recent announcement that offshore processing would be expanded to included all subsequent boat arrivals, media reports from Nauru have highlighted that 151 of the more than 400 asylum seekers who had been sent there by Australia for processing in late 2012 had been arrested for setting fire to the detention centre. ${ }^{2}$ Recent reports have also noted the mental and physical health concerns, and safety and security concerns, that are evident among asylum seekers who have been held in the offshore processing centres on Nauru and Papua New Guinea's Manus Island since late $2012 .^{3}$

The Labor government's adoption of offshore processing on Nauru and Manus Island is not new policy in Australia - the Coalition government first introduced it in 2001 in an attempt to deter the arrival of asylum seekers coming by boat to Australia. For many Australians this policy - known as the Pacific Solution - is inextricably linked to the Tampa, the Norwegian freighter that rescued hundreds of asylum seekers from a stricken boat sailing for Australia in August 2001. Its captain, Arne Rinnan, found himself at the centre of a

\footnotetext{
${ }^{1}$ T. Burke, Australia and Papua New Guinea regional settlement arrangement. Joint media release with Kevin Rudd - Prime Minister, Mark Dreyfus - Attorney General and The Hon Tony Burke MP - Australian Minister for Immigration, Multicultural Affairs and Citizenship, 19 July 2013, available at: http://www.minister.immi.gov.au/media/tb/2013/tb205550.htm (last visited 29 July 2013).

${ }^{2}$ L. Wilson, "Government defends processes", The Australian, 25 July 2013, available at: http://www.theaustralian.com.au/national-affairs/immigration/government-defends-processes/story-fn9hm1gu1226684608645 (last visited 29 July 2013).

${ }^{3}$ ABC, No Advantage, Four Corners, 2013, available at: http://www.abc.net.au/4corners/stories/2013/04/29/3745276.htm (last visited 29 July 2013); Amnesty International, What We Found on Nauru, 17 December 2012, available at: http://www.amnesty.org.au/refugees/comments/30726/ (last visited 29 July 2013); SBS (2013) "Rape and torture on Manus Island: whistleblower" Mark Davis, Dateline, 24 July 2013, available at: http://www.sbs.com.au/news/article/1791996/Rape-and-torture-on-Manus-Island-whistleblower (last visited 29 July 2013); UNHCR, UNHCR Mission to the Republic of Nauru 3-5 December 2012 Report, available at: http://unhcr.org.au/unhcr/images/Amended\%20footnote\%202012-1214\%20nauru\%20monitoring\%20report\%20final_2.pdf (last visited 29 July 2012); UNHCR, UNHCR Mission to Manus Island, Papua New Guinea 15-17 January 2013, 2013, available at: http://unhcr.org.au/unhcr/images/2013-02-04\%20Manus\%20Island\%20Report\%20Final.pdf (last visited 29 July 2013).
} 
diplomatic storm when the Australian Prime Minister John Howard insisted that the passengers would not set foot on Australian soil. The Coalition government soon established an agreement with the Pacific states of Nauru and Papua New Guinea to establish offshore processing centres on Australia's behalf. These were quickly constructed and the passengers who had been on the Tampa, and on other boats that arrived soon after, were taken to these island camps.

The majority of these asylum seekers were held in a processing camp on Nauru, a phosphate rock island in the Pacific Ocean that is the world's smallest independent republic. A population of approximately 10,000 lives on its 21 square kilometre landmass. ${ }^{4}$ Nauru is a remote island - it is three thousand kilometres north east of Australia and its nearest neighbour, the island of Kiribati, lies 300 kilometres to the east.

Of the 1,322 men, women and children who were detained on Nauru between 2001 and its closure in 2008, 573 (43 per cent) were finally resettled in Australia and 274 (21 per cent) were resettled in other countries, mostly in New Zealand. The vast majority of those resettled were accepted as refugees (90 per cent) while others were accepted on other humanitarian grounds. With the exception of one asylum seeker who died while detained on Nauru, the remaining 475 (36 per cent) were repatriated to their countries of origin. ${ }^{5}$ Asylum seekers from Afghanistan accounted for 786 of the asylum seekers detained on Nauru. Of these, 366 were eventually accepted as refugees or humanitarian entrants, and 420 were returned to Afghanistan. ${ }^{6}$

In this paper, we draw on the experiences of Afghan asylum seekers held on Nauru under the Coalition government's offshore processing policy to highlight the experiences of those whose lives were most affected by the policy. There are numerous accounts of life in the offshore processing centre on Nauru from 2001 until it was closed in 2008 (the year following the election of the Labor government), despite the difficulties for Australians independent of the government to access the centres for most of the years of their operation. Some Australian refugee advocates corresponded by mail with asylum seekers on Nauru. A

\footnotetext{
${ }^{4}$ Department of Foreign Affairs and Trade, Nauru Country Brief, June 2013, available at: http://www.dfat.gov.au/geo/nauru/nauru brief.html (last visited 9 August 2013).

${ }^{5}$ W. Southern, Deputy Secretary of Department of Immigration and Citizenship, Official Committee Hansard, Senate, Legal and Constitutional Affairs Legislation Committee, Estimates, 17 October 2011, http://www.aph.gov.au/Parliamentary_Business/Committees/Senate_Committees?url=legcon_ctte/estimates/sup _1112/i ndex.htm (last visited 10 September 2012), 143; M. Gordon, “The 'Pacific Solution”" in D. Lusher \& N. Haslam, (eds) Yearning to Breathe Free: Seeking Asylum in Australia, Federation Press, Leichhardt NSW, 2007, 76.

${ }^{6}$ J. Phillips, The 'Pacific Solution' Revisited: A Statistical Guide to the Asylum Seeker Caseloads on Nauru and Manus Island, Parliament of Australia, Parliamentary Library, 4 September 2012, 14.
} 
few advocates, journalists and lawyers managed to secure visas or passes to visit the island. Regular visitors to Australia's immigration detention centres have gotten to know some of the former Nauru detainees who were returned to Afghanistan but once again came to Australia seeking asylum several years ago. The discussion to follow is drawn from the public accounts of those advocates, journalists and lawyers who corresponded with or visited asylum seekers on Nauru. ${ }^{7}$ It also draws on research undertaken on the experiences of asylum seekers who were returned to their countries of origin after detention in Australia, Nauru or Manus Island. ${ }^{8}$ In addition, this paper draws on the interviews and communications the authors have had with three asylum seekers who were detained on Nauru, returned to Afghanistan, and have since returned to Australia.

The experiences of those held on Nauru under the Coalition government will be explored here using a governmentality approach. As Australia has established offshore processing on Nauru and Papua New Guinea once again, this time under a Labor government, this paper's findings are instructive for critiques of current policy.

\section{Governmentality}

Michel Foucault introduced the concept of "governmentality" which he once described as the "art of government". ${ }^{9}$ It is concerned with how governments govern; the institutions, methods, techniques, strategies and tactics they use to achieve their goals including measures taken to foster the compliance of those being governed. Foucault argued that an analysis of what a government did was more revealing of the mentality or rationale that lay behind such action, than conducting an analysis through the prism of an ideology such as, for example, communism or liberalism. He considered that undertaking an analysis according to ideology limits the analysis because any government action that sits outside of that ideology tends to be overlooked. $^{10}$

\footnotetext{
${ }^{7}$ Most notably, these include the published accounts of Metcalfe (2010) and Gordon (2007) who both visited Nauru on a number of occasions, and the letters from asylum seekers sent to refugee advocates contained in the Burnside/Durham collection in the Fryer Library, University of Queensland. M. Gordon, Freeing Ali: The Human Face of the Pacific Solution, University of NSW Press, Sydney, 2005; S. Metcalfe, The Pacific Solution, Australian Scholarly Publishing, North Melbourne, 2010.

${ }^{8}$ D. Corlett, Following Them Home: The Fate of the Returned Asylum Seekers, Black Inc., Melbourne, 2005; Edmund Rice Centre for Justice and Community Education, Deported to Danger: A Study of Australia's Treatment of 40 Rejected Asylum Seekers, September 2004; Edmund Rice Centre, Deported to Danger II: The Continuing Study of Australia's Treatment of Rejected Asylum Seekers, September 2006.

${ }^{9}$ T. Lemke, An Indigestible Meal? Foucault, Governmentality and State Theory, 2007, available at: http://www.thomaslemkeweb.de/publikationen/IndigestibleMealfinal5.pdf (last visited 5 August 2013).

${ }^{10}$ S. Hoffman, Fear, Insecurity and Risk: Refugee journeys from Iraq to Australia, doctoral thesis, Murdoch University, Perth, 2010, 53.
} 
Foucault argued that there are three modes by which governments govern sovereignty, discipline and governmentality - and that these three coexist and support each other. Sovereign power is evident through the exercise of law and military deployment. Discipline in the Foucaultian sense refers to how institutions such as prisons, factories and schools control and standardise behaviour of inmates, workers and pupils. ${ }^{11}$ It encourages self-regulation and bears more resemblance to training than coercion. ${ }^{12}$ Governmentality is concerned with the strategies and tactics used by government to shape and influence the attitudes, beliefs and behaviours of resident populations. Examples include campaigns aimed to reduce the incidence of smoking or drink-driving. Typically, other organisations are recruited to actualise government aims and policy. Using Foucault's terminology, these are the government's "apparatuses of security" which include the military, police and government agencies as well as non-government organisations and private companies. ${ }^{13}$

Although more typically used when considering how governments exercise authority over their own citizens, the governmentality approach has been used to analyse government responses to global concerns such as terrorism ${ }^{14}$ and the international response to refugee management. Lippert identified the refugee camp, introduced in the twentieth century, as a technology used to discipline refugees in the governmental sense. ${ }^{15}$ Refugee camps were perceived to be an "efficient means of providing aid and segregating refugees of different nationalities" and as bearing similarities to "barracks, asylums, schools, and prisons" while being none of these. ${ }^{16}$ Like inhabitants of prisons and asylums, refugees in camps were segregated from the wider community and given little opportunity to exercise choice. They did not enjoy the freedoms afforded to the majority of citizens, as inhabitants did not generally have access to education, employment or the rights to purchase property that are assumed to be afforded to citizens. As with school students, soldiers in barracks, and prison and asylum inhabitants, refugees in camps are subject to monitoring and behavioural constraints that go far beyond that to which other citizens are subject. Such institutions shape behaviour to accord with what authorities deem to be acceptable. As Lippert observed, these

\footnotetext{
${ }^{11}$ P. Harris, "Public Welfare and Liberal Governance", in A. Petersen, I. Barns, J. Dudley, \& P. Harris, (eds) Poststructuralism, Citizenship and Social Policy, London, Routledge, 1999, 31.

${ }^{12}$ L. Ruhl, "Liberal Governance and Prenatal Care: Risk and Regulation in Pregnancy”, in P. O’Malley (ed.), Governing Risks, Aldershot UK, Ashgate, 2005, 75.

${ }^{13}$ D. Holmes \& D. Gastaldo, D. "Nursing as Means of Governmentality", Journal of Advanced Nursing, 38(6), 2002, 557-565, 559.

${ }^{14}$ C. Aradau \& R. Van Munster, “Governing Terrorism and the (non) Politics of Risk”, Political Science Publications, 11, University of Southern Denmark, 2006.

${ }^{15}$ R. Lippert, "Governing Refugees: The Relevance of Governmentality to Understanding the International Refugee Regime", Alternatives, 24(3), 1999, 295-328, 308-310.

${ }^{16}$ Lippert, "Governing Refugees", 309.
} 
lead to judgements of individuals' characters according to their degree of conformity to, or deviation from, the norm so established. ${ }^{17}$

Crisp and Jacobsen refer to the enormous variety in "size, socio-economic structure and political character" of refugee camps. ${ }^{18}$ The authors refer to crisis situations where refugees, having fled immediate danger, effectively create refugee camps to which international bodies then provided support. Those within these camps found that living with people of shared background provided a sense of safety and security. In such camps, there were no restrictions on movement between the camps and local villages and towns. In contrast, many refugee camps established by governments are done so with the intent of preventing camp inhabitants from mixing with local people; and to facilitate repatriation.

As well as changes from camp to camp, there were changes across time. Post world war two, camp inhabitants were given tasks to keep them busy and evaluated for selection for settlement elsewhere according to how well they conformed to camp discipline. In the 1980s, there were growing concerns of the damage done by long term institutionalisation which might prevent a camp inhabitant being able to live independently. ${ }^{19}$ The response to this, more evident in the 1990s, was a move to 'empower' refugees with camp inhabitants encouraged to take a larger role in managing the camp and to take more responsibility for their own lives. Non-government organisations that until then were largely involved in dispensing aid, began to engage in "community development" activities in the camps. ${ }^{20}$

Australian immigration detention centres and their offshore equivalents share some of the characteristics of refugee camps established by governments. The majority of those held in the Nauru offshore processing centre were eventually found to be refugees. In Nauru, as with refugee camp inhabitants, the asylum seekers did not enjoy the same rights of Nauruan citizens. They did not have access to employment or education, or the freedom to live where they liked on the island. However, as will be explored later, unlike the approach taken in refugee camps in the 1990s that Lippert highlights, there was little evidence that the Australian Coalition government was concerned with the welfare of the Nauru offshore processing centre's inhabitants. To the contrary, the authors argue that the harsh conditions of the Nauru centre were a tactic of government to encourage asylum seekers to give up their refugee claims and return to their home country. In other words, the conditions in the Nauru processing centre were designed to persuade asylum seekers to adopt compliant behaviour.

\footnotetext{
${ }^{17}$ Ibid.

${ }^{18}$ J. Crisp \& K. Jacobsen “Refugee Camps Reconsidered”, Forced Migration Review, 3, 1998, 27 - 30, 27.

${ }^{19}$ Lippert, "Governing Refugees", 309.

${ }^{20} \mathrm{Ibid}, 313 \mathrm{f}$.
} 
In giving effect to a policy objective, governments rely on their apparatuses of security (for example, military, police, government agencies, non-government organisations and private companies) drawn from the general population. It is therefore in a government's interests to make policy palatable to the broader community To bring this about, they may choose to frame a policy debate in a particular way to heavily influence public discourse, and hence public opinion, on a particular topic. Other tactics used by government to bolster public support of its policies include controlling access to information that might cause a negative response from the public. ${ }^{21}$ This can be facilitated by a government enlisting the aid of other organisations to achieve its ends through contracting out its functions and then maintaining control through the conditions of that contract. All of these can be seen in relation to the establishment and defence of the Pacific Solution.

To explore the experiences of asylum seekers held in the offshore processing centre on Nauru according to a governmentality approach, we now consider the physical conditions of the centre and the processing of refugee claims from the perspectives of some of the Afghan asylum seekers. We explore these aspects as examples of how the Coalition government sought to persuade asylum seekers to adopt compliant behaviour, and how other bodies were utilised by the Coalition government to actualise its policy. We then examine the way in which the government garnered the support of the Australian population. We conclude by reflecting on the findings of this paper in the context of what is known to date about Australia's current offshore processing on Nauru.

\section{The experiences of asylum seekers on Nauru under Coalition policy}

\subsection{Physical conditions}

The physical conditions of the processing centre on Nauru under Coalition government policy were harsh. When the first asylum seekers arrived on Nauru in September 2001, they were housed in a campsite containing large tents that each accommodated up to thirty people. After some months, metal containers that held fifteen people were erected to replace the tents, and a second campsite was later established as more asylum seekers were sent to Nauru. Both sites were enclosed with high wire fences. ${ }^{22}$ These developments did little to compensate for the oppressive weather conditions on Nauru and little relief from the humidity was provided.

\footnotetext{
${ }^{21}$ S. Pickering, Refugees and State Crime. Sydney: The Federation Press, 2005.

${ }^{22}$ J. Browning, States of Exclusion: Narratives from Australia's Immigration Detention Centres, 1999-2003, $\mathrm{PhD}$ thesis, University of Technology, Sydney, 2006, 179.
} 
In the first six months electricity was only provided to the communal areas of the campsites that meant that there were no means to cool or light the sleeping areas. ${ }^{23}$ Being a tropical island with hot and humid weather, Nauru also had a high mosquito population.

It was terrible. The roofs were made of metal and some days the temperature was over 50 degrees under the metal. The walls were plastic. The houses were too long and too hot. These were not conditions for humans. ${ }^{24}$

Given Nauru's remoteness, fresh food was in short supply in the detention camps and there were reports that the food was often stale and sometimes insects were found in it. There was also little drinkable water in the detention camps, and the situation worsened as the number of those detained on Nauru increased. Often there would be no water for washing clothes, flushing the toilet or for taking a shower, creating unsanitary conditions.

The unavoidable consequence of water shortage is lack of sanitation and cleanliness. Our toilets and bathrooms are particularly very dirty and harbour several types of flies and mosquitoes...medical team called us for a meeting and said the increase of diarrhoea is alarming. There are two bloody diarrhoea cases hospitalised at present. The doctors say that our surroundings is not clean and hygienic, and its main cause is shortage of water. ${ }^{25}$

The unsanitary conditions led to further incidences of diarrhoea and other medical problems, such as gastro-intestinal diseases, skin and eye infections, and dengue fever. ${ }^{26}$ The lack of adequate medical care on Nauru meant that asylum seekers with conditions requiring specialist attention had to wait lengthy periods for it, with some finally being flown to Australian hospitals to receive it. ${ }^{27}$ The consequences for these asylum seekers meant months of pain and suffering that could have been averted or at least minimised should they have been near appropriate medical facilities.

\footnotetext{
23 Ibid.

${ }^{24}$ Asylum seeker interviewed by Edmund Rice Centre, Deported to Danger II, 25.

${ }^{25}$ Letter from asylum seeker to refugee advocate in Australia, 16 May 2003, located in the Burnside/Durham Collection, Fryer Library, University of Queensland.

${ }^{26}$ Browning, States of Exclusion, 181; Metcalfe, The Pacific Solution, 69.

${ }^{27}$ ABC, "Asylum seekers' health under the microscope",, The World Today, 8 July 2003, available at: http://www.abc.net.au/worldtoday/content/2003/s897542.htm (last visited 10 April 2012).
} 
Opportunities for communication with anyone outside of the processing campsites were also severely limited, particularly in the first few months. When asylum seekers first arrived on Nauru, they were unable to make phone calls to their families or anyone else. There was no access to radio, television or newspapers in the first months of the camp and thus no access to information on what was happening in their own countries. After some months, phones became available but only a few people each day were able to make calls. ${ }^{28}$ This meant that asylum seekers "could not contact our families to find out what was happening at home". ${ }^{29}$ Some of those who were later returned to their home countries discovered upon their arrival that their families had moved. ${ }^{30}$

Movement outside the camps was possible from early 2002 but always subject to surveillance or restrictions. Initially asylum seekers were allowed to leave the camp with an escort and visit the local shops or internet café. By late 2004 they were allowed to visit the shops, internet café or an area for swimming where "zone escorts" would observe them. ${ }^{31}$ By March the following year asylum seekers were allowed to leave the camp during the day, but if anyone "wandered into the off-limits areas of the airport, the hotel, or government offices, or were late arriving back to the gates of the camp, or argued with [Australian Protective Services], they could be gaoled". 32

The harshness of the physical conditions of the processing centre on Nauru was a reflection of the Coalition government's intention to persuade asylum seekers to abandon their claims for refugee status and voluntarily return to their own countries, and the hosting and management of the camps is an example of the Coalition government's recruitment of other bodies to actualise its policy. The Nauru government was persuaded with the offer of a considerable increase in Australian aid to host a site of detention on behalf of Australia. ${ }^{33}$ Consistent with the Coalition government's practice of contracting out the operations of the Australian immigration detention centres since 1996, most of the functions within the Nauru camps were outsourced. The Eurest company provided the catering and the security of the

\footnotetext{
${ }^{28}$ Browning, States of Exclusion, 179; Metcalfe, The Pacific Solution, 29, 109.

${ }^{29}$ Edmund Rice Centre, Deported to Danger II, 13.

${ }^{30}$ One of the asylum seekers detained on Nauru from 2001 to 2003 returned back to Afghanistan to find his family had disappeared. He has since returned to Australia and been found to be a refugee. As at August 2012, he has still not been able to find out what happened to his family. Interview, Perth, January 2012.

${ }^{31}$ Gordon, Freeing Ali, 84.

${ }^{32}$ Metcalfe, The Pacific Solution, 198.

${ }^{33}$ For example, as it became clear that the asylum seekers held on Nauru would not be processed by the end of 2001, the Australian government agreed to provide A $\$ 26.5$ million to Nauru for the two year period 2001-2003. Senate Select Committee on a Certain Maritime Incident, A Certain Maritime Incident, 23 October 2002, available at: http://www.aph.gov.au/Parliamentary Business/Committees/Senate_Committees?url=maritime incident_ctte/re port/index.htm (last visited 29 July 2013), 298.
} 
camps was provided by the Chubb company, although the government agency Australian Protective Services was responsible for the security services of the camps. The International Organisation of Migration (IOM) was contracted to manage most of the other operations of the camps. ${ }^{34}$ While the IOM was not responsible for establishing the physical conditions of the camps, and some argue that it sought to "minimise the hardship of those in its care", 35 it remained willing to manage most of the operations of the camps until they were closed in 2008. Similarly, the Nauru government remained willing to host the camps on their territory. Using Foucault's terminology, these bodies, particularly the Nauru government and the IOM, were Australian government apparatuses of security that enabled the offshore processing policy to be executed on Nauru.

A consequence of involving other bodies and individuals in Australia's offshore processing policy, some of whom might not be predisposed to be supportive of government policy, was an increased risk of information about conditions in the Nauru camps being communicated to the Australian public, and hence, increased opposition to the policy. To minimise this risk, the Coalition government required contractors to sign confidentiality agreements. $^{36}$

The contracting of others as apparatuses of security also meant that a barrier was placed in the way of any Australians independent of their government being able to access the camps, particularly from 2001 to 2004. For example, aside from being contracted to host the offshore processing camps, the Nauru government enabled the Coalition government to limit any external scrutiny of the centre. For the first few years of the camps' operations, the Nauru government refused to issue visas to anyone wishing to visit the camps, including Australian migration agents who wanted to represent the asylum seekers pro bono. It was not until 2004, when DIMIA finally permitted migration agents access to asylum seekers to provide legal advice, that Nauru issued some visas accordingly. ${ }^{37}$ In this way, except for the clandestine visits of two journalists and a human rights advocate who had posed as tourists in $2002,{ }^{38}$ the conditions for asylum seekers held on Nauru were kept largely hidden from most of the Australian population for the first three years of the camps' operations.

\footnotetext{
${ }^{34}$ Metcalfe, The Pacific Solution, 29.

${ }^{35}$ Gordon, Freeing Ali, 84.

${ }^{36}$ D. Zion, L. Briskman \& B. Loff, "Nursing in asylum seeker detention in Australia: care, rights and witnessing”, Journal of Medical Ethics, 35, 2009, 546-551.

${ }^{37}$ L. Briskman, S. Latham \& C. Goddard, Human Rights Overboard, Melbourne, Scribe Publishing, 2008, 108; Metcalfe, The Pacific Solution, 15, 45-46.

${ }^{38}$ Gordon, Freeing Ali, 20.
} 


\subsection{Processing of refugee claims}

The initial processing of the refugee claims of asylum seekers on Nauru provides another example of the Australian government's recruitment of apparatuses of security, in addition to clearly reflecting the government's intention to change the behaviour of asylum seekers. As cited earlier, 64 per cent of the asylum seekers detained on Nauru, including Afghans, were eventually found to be refugees or owed protection under other humanitarian grounds. However, this does not account for the strong possibility that many others on Nauru were also likely to have been owed protection. As remarked by one of the men detained on Nauru, "asylum seekers are presumed guilty until proved innocent."39

Many reports from asylum seekers, lawyers and advocates highlight the "lack of natural justice and fairness" in the refugee claims process on Nauru ${ }^{40}$ and that it was "a repudiation of Australia's obligations under the Refugee Convention". ${ }^{41}$ Despite the fact that many of those detained on Nauru were ultimately returned to their own countries, suggesting that offshore processing was able to return those without legitimate claims for asylum, this claim does not hold up to closer scrutiny.

Most of the refugee claims of asylum seekers on Nauru were processed by Australia's Department of Immigration and Indigenous Affairs (DIMIA). ${ }^{42}$ However, the UN High Commissioner for Refugees (UNHCR) did agree to process some of the early arrivals, in effect providing a measure of support to the offshore processing policy and the deeply flawed processing that followed. ${ }^{43}$ There was no independent oversight of the processing, no legal advice or representation made available to the asylum seekers, and no capacity for judicial review of the negative decisions decided by either DIMIA or the UNHCR. Until 2004 it was impossible for any Australian migration agents or lawyers to even voluntarily represent any of the asylum seekers, as visas to visit Nauru up until that time had been denied. Migration agent Marion Le was allowed access to Nauru in 2004 to represent asylum seekers, although her work and those of her two assistants was not funded, and she remained the only agent with DIMIA permission to do so until $2006 .^{44}$

\footnotetext{
${ }^{39}$ Written in a letter from an asylum seeker on Nauru to a refugee advocate in Australia, dated 14 January 2002, Burnside/Durham Collection.

${ }^{40}$ S. Metcalfe, quoted in Gordon, "The 'Pacific Solution"”, 2007, 85.

${ }^{41}$ Briskman, Latham \& Goddard, Human Rights Overboard, 2008, 105.

${ }^{42}$ Now called the Department of Immigration and Citizenship.

${ }^{43}$ ABC Radio National,"Levelling the Playing Field or Curbing Fundamental Rights?” Law Report, 2 October 2001, available at: http://www.abc.net.au/cgibin/common/printfriendly.pl?http://www.abc.net.au/rn/talks/8.30/lawrpt/stories/s380546.htm (last visited 20 August 2012).

${ }^{44}$ Metcalfe, The Pacific Solution, 15, 45-46; Briskman, Latham \& Goddard, Human Rights Overboard, 108.
} 
Those first detained on Nauru from September 2001 had to wait over seven months for the initial decisions on their refugee claims to be released. By this time, many had endured three or more interviews from DIMIA or UNHCR officials. ${ }^{45}$ In part the delay reflected the changing political circumstances in Afghanistan - in October 2001 Afghanistan was invaded by the US and its allies, leading to the demise of the Taliban regime and the installation of an interim government in early 2002.

The anguish that the interviews created for asylum seekers was acute: "everyone was afraid because it was the matter of death and life. If they reject your case everything will finish." 46 Many asylum seekers continued to be afraid throughout the period leading up to their initial decisions. Letters to advocates in Australia highlighted their growing concerns, including about the lack of legal representation:

We know that the International Refugee Convention and human rights principles provide an asylum seeker the right to seek legal advice and to present his claim to a court. We are concerned that a genuine refugee might lose the right of protection, not because of invalid claims but because of not knowing the law, and lack of education, and the ability to present his story well. ${ }^{47}$

By June 2002 most Afghan asylum seekers on Nauru whose refugee claims had been processed had received negative initial decisions - only six out of 114 Afghan asylum seekers processed by DIMIA were recognised as refugees, and 25 out of 244 Afghan asylum seekers processed by UNHCR. ${ }^{48}$ While DIMIA processing of refugee claims on the Australian mainland at this time had also resulted in low acceptance rates, ${ }^{49}$ the right of asylum seekers in Australia to have their decisions reviewed by the Refugee Review Tribunal (RRT) meant that many of these decisions were later overturned upon independent review. ${ }^{50}$ Asylum

\footnotetext{
${ }^{45}$ Browning, States of Exclusion, 188-89; Metcalfe, The Pacific Solution, 96.

${ }^{46}$ Written account of being detained on Nauru by former detainee, given to authors.

${ }^{47}$ Letter to refugee advocate in Australia, 24 December 2001, Burnside/Fryer Collection.

${ }^{48}$ DIMIA, “Asylum decisions handed down on Nauru”, Media Release, 13 June 2002, available at: http://www.newsroom.immi.gov.au/media_releases/564 (last visited 10 April 2012).

${ }^{49}$ Briskman, Latham \& Goddard, Human Rights Overboard, 106.

${ }^{50}$ In 2001-2002 the RRT had set aside 62 per cent of negative Afghan decisions and 87 per cent of negative Iraqi decisions. In 2003-2004 the RRT had set aside 90 per cent of negative Afghan decisions. Refugee Review Tribunal (2002) Annual Report 2001-2002, 2002, available at: http://www.mrtrrt.gov.au/ArticleDocuments/121/RRTAR0102.pdf.aspx (last visited 30 August 2012); Refugee Review Tribunal, Annual Report 2003-2004, 2004, available at: http://www.mrtrrt.gov.au/ArticleDocuments/121/RRTAR0304.pdf.aspx (last visited 30 August 2012).
} 
seekers on Nauru were not afforded the right to have their claims decisions independently reviewed.

Letters to advocates in Australia show that Afghan asylum seekers on Nauru understood that the changing political circumstances in Afghanistan in the aftermath of the US invasion was a key factor in so many of their claims being rejected. There were also reports of inconsistencies between decisions. For example, within a single family, some claims were accepted while close relatives' claims were rejected. There were even cases of men whose refugee claims were rejected even though their wives had been accepted as refugees. ${ }^{51}$ Complaints were made about some of the interpreters employed by DIMIA and the UNHCR. According to letters sent to advocates, "many Afghan detainees...believed that at least two of the Afghan interpreters used by both DIMIA and UNHCR were hostile to the claims made by Hazara Afghans". 52 Most interpreters used by DIMIA and UNHCR were from Pashtun and Tajik Afghan communities whereas most Afghan asylum seekers were members of the Hazara ethnic minority. Historically there has been much hostility between Hazaras and the larger Pashtun and Tajik communities, and many Hazaras had fled Afghanistan because of the persecution they faced by the Pashtun-dominated Taliban. ${ }^{53}$

For many [Hazara asylum seekers] this...meant that their interviews were conducted in an atmosphere of distrust, and claims based on persecution from the majority Pashtuns in their country were almost impossible to discuss through an intermediary from the same ethnicity. 'If we complained about the Pashtuns or the Taliban there would be trouble if we were sent back, so we couldn't tell the truth', says one man. ${ }^{54}$

The majority of Afghans on Nauru found themselves in limbo after their claims were rejected and towards the end of 2003, some of them participated in a hunger strike and sewed their lips together. ${ }^{55}$ The hunger strike ended after a month when the Minister for Immigration and Multicultural Affairs, Amanda Vanstone, announced that the refugee claims rejected by

\footnotetext{
${ }^{51}$ Browning, States of Exclusion, 205-6.

${ }^{52}$ Ibid, 191. h

${ }^{53}$ W. Maley, On the Position of the Hazara Minority in Afghanistan

7 December 2011, 2011, available at: http://bmrsg.org.au/links/facts-about-refugees/ (last visited 29 March 2012).

${ }^{54}$ Metcalfe, The Pacific Solution, 74.

${ }^{55}$ Australian Government, "Report of Health Team on Health Services for Asylum Seekers in Nauru: 12-14th January 2004”, 29 January 2004; Letter from asylum seeker on Nauru to advocate in Australia, 1 February 2004, Burnside/Durham Collection.
} 
DIMIA would be assessed again based on new country information on Afghanistan. It was at this time that Marion Le was finally allowed to visit Nauru and represent the Afghans. Neither she nor her two assistants were funded to do this work and she remained the only agent with DIMIA permission to do so until $2006 .^{56}$ Meanwhile the UNHCR also reviewed its rejected claims and declared that all 22 of its remaining cases on Nauru were refugees. DIMIA found 146 of its remaining 175 cases on Nauru to be refugees. ${ }^{57}$

By this time, however, other Afghans had simply given up and left after being told that their refugee claims had been rejected and that they should return to Afghanistan. Given Australia's agreement with Nauru that asylum seekers would only be detained on the island for a "reasonable timeframe", the Australian government sought to ensure that all asylum seekers were either repatriated or resettled as soon as possible. ${ }^{58}$ To this end, in May 2002 the Australian government signed a Memorandum of Understanding with the interim Afghan government allowing for the voluntary return of asylum seekers. ${ }^{59}$ In September 2002 those whose claims had failed were informed that there was now a new government in Afghanistan and thus the reasons for fleeing no longer existed; they had to return home. The Australian government offered them a repatriation package of $\$ 2,000$ per person or $\$ 10,000$ per family if they agreed to return to Afghanistan within 28 days of being notified that their refugee claim had failed, ${ }^{60}$ a blatant attempt to pressure the asylum seekers into compliance.

The anguish that these rejections generated was widespread and letters to advocates in Australia talked of desperate self-harm attempts. ${ }^{61}$ The despair and attendant behaviours had become so extreme that others started to speak out. In 2002 the IOM head psychiatrist on Nauru, Maarten Dormaar, reported that after three months in detention most young men who had previously been healthy were exhibiting “clear symptoms of suffering or distress". These symptoms included "sleeping difficulties, constant worrying (about the future, the family in Afghanistan and the possible dangers encountered on return), social withdrawal, not enjoying life anymore and being easily irritated or upset". ${ }^{62}$

\footnotetext{
${ }^{56}$ Metcalfe, The Pacific Solution, 15, 45-46; Briskman, Latham \& Goddard, Human Rights Overboard, 108.

${ }^{57}$ Gordon, Freeing Ali, 46-49.

${ }^{58}$ Browning, States of Exclusion, 203.

${ }^{59}$ Minister for Immigration and Multicultural and Indigenous Affairs, Media Release, MPS 34/2002, 17 May 2002.

${ }^{60}$ Minister for Immigration and Multicultural and Indigenous Affairs, Media Release, MPS 38/2002, 23 May 2002.

${ }^{61}$ E. Smith, Submission to the Inquiry into the Provisions of the Migration Amendment (Designated Unauthorised Arrivals) Bill 2006; Burnside/Durham Collection.

${ }^{62}$ Quoted in Metcalfe, The Pacific Solution, 106; see also ABC Lateline "Nauru camps "psychiatrist's nightmare': doctor", 15 May 2003, available at: http://www.abc.net.au/7.30/content/2003/s855996.htm (last visited 12 August 2013).
} 
DIMIA continued to pressure failed asylum seekers to return to their own countries. It told asylum seekers in writing that:

You may not stay in Nauru indefinitely and there is no chance of you going to Australia by staying here longer... The Australian Government is exploring all options for return including involuntary return. ${ }^{63}$

The despair that the claims processing and pressure to return home created in asylum seekers on Nauru intensified over the months that followed the initial rejections.

I'm not sure what to do should I go back or should I stay here. I can't make my decision. It's like I'm hanging in the air and got nowhere to go...I can't go back to my home land to the same misery and brutality. ${ }^{64}$

There were many incidents of self-harm and very little care provided for those with growing mental health issues.

Two weeks ago a detainee tried to commit suicide. He hit his body with a blade in his room. Someone had seen blood on his abdomen while he was going to bathroom. When we went to bathroom the door was closed...After a few minutes we opened the door and found him lying on the floor and the blood was coming from his body. The security guards also arrived and we took him to the main gate of detention for medication. The security guards took him to hospital. He is still in IOM's clinic in State House detention centre. ${ }^{65}$

As time went on, many of the Afghan asylum seekers felt they had no option but to return to Afghanistan. Reports have surfaced of "subtle threats from the guards [on Nauru] about injections for those unwilling to go back". ${ }^{66}$ Consistent with this, one man wrote to an Australia-based advocate:

\footnotetext{
${ }^{63}$ Quoted in Gordon, Freeing Ali, 37-38.

${ }^{64}$ Letter from asylum seeker on Nauru to refugee advocate in Australia, 29 July 2003, Burnside/Durham Collection.

${ }^{65}$ Letter from asylum seeker on Nauru to Elaine Smith, quoted in Smith, Submission to the Inquiry.

${ }^{66}$ Edmund Rice Centre, Deported to Danger, 26.
} 
[1]ast week IOM and DIMIA warned those detainees who have not prepared to return, that they must take a decision to return voluntarily before the government take any action to repatriate them by force and they should not think that the government would allow them to enter in Australia. ${ }^{67}$

One former Nauru detainee, who was returned to Afghanistan but sought asylum in Australia again seven years later, said that he felt he had "no choice" about returning to Afghanistan.

If I had known after five years I would have been accepted, I would have stayed...We didn't understand [about the situation in Afghanistan] because we didn't have any communication, any telephone contact, email, nothing. ${ }^{68}$

Most of the 475 asylum seekers who were repatriated to their own countries from Nauru were returned to Afghanistan. Aside from the Australian government's repatriation package that some asylum seekers had accepted, there was little or no further support provided upon their return.

The Edmund Rice Centre interviewed 36 returned Afghan Hazaras in 2006, most of who had been detained on Nauru, and all said they had not been safe upon their return to Afghanistan. All but one had left Afghanistan and fled to Pakistan or Iran. ${ }^{69}$ Former Nauru detainees who kept in touch with advocates in Australia told of fleeing Afghanistan within weeks of their return. ${ }^{70}$

After 20 days staying in Kabul we were compelled to leave Kabul because we didn't have any residency to live in and we were afraid of going back to our village and cities, most of us couldn't find our families so we managed to leave Afghanistan again. Some went to other cities, some went to Iran and I with 11 other refugees came to Peshawar. We are still searching for our families. ${ }^{71}$

\footnotetext{
${ }^{67}$ Quoted in Smith, Submission to the Inquiry.

${ }^{68}$ Interview, Perth, January 2012.

${ }^{69}$ Edmund Rice Centre, Deported to Danger II, 2, 41.

${ }^{70}$ Browning, States of Exclusion, 209; Burnside/Durham Collection.

${ }^{71}$ Letter from returned asylum seeker from Nauru to advocate in Australia, 3 February 2003, Burnside/Durham Collection.
} 
Gholam, an Afghan Hazara who had been detained on Nauru, had asked his family to leave Iran and meet him in Kabul. After four months his house was bombed killing one of his daughters and fatally wounding the other, and seriously injuring his wife and mother.

I told Australia what would happen if we returned to Afghanistan and it happened. House bombed. Children dead. Mother and wife badly hurt, mother never to recover...We got caught up in Australian politics... My children died so John Howard could win an election. ${ }^{72}$

The consequences of the Coalition government's success in persuading hundreds of asylum seekers to return to their own countries were dire for at least some of those who were returned. It is very likely that such outcomes were evident for more of those returned.

As outlined in the previous section, the Coalition government had contracted out its apparatuses of security in establishing and operating the offshore processing centre on Nauru, and was able to influence the actions of its contracted bodies. This was similarly evident to some extent with the claims processing, in the ability of the Coalition government to get the involvement of the UNHCR, at least initially, to help process the refugee claims of some of the asylum seekers who arrived in the beginning. However, this case also highlights the limits of the Coalition government's ability to recruit this particular body as one of its apparatuses of security. The UNHCR's mandate is to provide for the protection of refugees, and to only assess the protection claims of asylum seekers who arrive in countries where governments do not have the resources to do so themselves. The Coalition government's request that the UNHCR undertake the processing of protection claims on Nauru placed the international agency in a compromised position. As the UNHCR relies on funding from member nations, especially those of the wealthier nations, it strives to maintain good relations with countries like Australia. Accordingly, the UNHCR agreed to process the refugee claims of the asylum seekers who had arrived on two of the early boats but it refused to process any further arrivals. It also made public its concerns about being asked to process asylum seekers on Nauru. $^{73}$

\footnotetext{
${ }^{72}$ Edmund Rice Centre, Deported to Danger II, 25.

${ }^{73}$ ABC Radio National, "Levelling the Playing Field or Curbing Fundamental Rights?" Law Report, 2 October 2001, http://www.abc.net.au/cgibin/common/printfriendly.pl?http://www.abc.net.au/rn/talks/8.30/lawrpt/stories/s380546.htm (last visited 20 August 2012).
} 
Another example of support that was provided by the Coalition government's apparatuses of security to government policy relates to the efforts to persuade Afghan asylum seekers to return home. The government's efforts to return asylum seekers to Afghanistan in 2002 were supported by the UNHCR and IOM. ${ }^{74}$ For example, in an attempt to reinforce that it was now safe for Afghan asylum seekers to return to their own country, in December 2002 DIMIA released a report on the Transitional Government in Afghanistan. The report drew attention to the fact that the UNHCR supported the return of asylum seekers, although the report's findings were soon challenged by several researchers on Afghanistan who suggested that UNHCR support for states' attempts to repatriate to Afghanistan was likely to reflect is reliance on its state funders. ${ }^{75}$ As indicated in one of the quotes above from asylum seekers on Nauru, the IOM actively supported the government's attempts to return asylum seekers. Its employees persistently pressured those asylum seekers who received negative decisions on their refugee claims to return to their countries. ${ }^{76}$

\section{Public support}

The Australian government received overwhelming public support in establishing the Pacific Solution following a concerted campaign by the government to portray asylum seekers as deviant, especially in the wake of the terrorist attacks in the US on 11 September 2001. As Dean $^{77}$ argues, there is a moral dimension in seeking to shape community attitudes and behaviours, as in so doing government purports to know what kind of behaviour is right, decent and proper. Framing the debate to reflect this allows government to justify and normalise its own actions. The targets of such government campaigns and debate, if they fail to conform or comply, may be denigrated as being deviant. By labelling groups of people as deviant, the door is open for governments to treat them differently to others in the community. ${ }^{78}$

According to government ministers, asylum seekers were people who were threatening Australia's border security, who were 'queue-jumpers' and might be terrorists or diseasecarriers. They were not like 'us'. They were Muslims, they threw their children overboard,

\footnotetext{
${ }^{74}$ Corlett, Following Them Home, 61-62.

${ }^{75}$ W. Maley, "Comments on Events in the Islamic Transitional Government of Afghanistan” 26 May 2003 ; D. Turton \& P. Marsden, "Taking Refugees for a Ride? The politics of refugee return to Afghanistan", Islamabad: Afghanistan Research and Evaluation Unit, 2002, 56.

${ }^{76}$ Metcalfe, The Pacific Solution, 141.

77 M. Dean, Governmentality: Power and Rule in Modern Society, London, Sage Publications, 1999, 11.

78 P. O’Malley, “Globalizing Risk? Distinguishing Styles of Neo-Liberal Criminal Justice in Australia and the USA”, Criminal Justice, 2(2), 2002, 205-222, 210.
} 
they were forum shoppers and they were not welcome. ${ }^{79}$ Locking people up at such a distance from the mainland fed into the perception that such people should be kept apart from the general community because of some deviant characteristic. The government's actions were perceived as being strong and decisive and the voices of those who called for a more compassionate and/or rights-based response struggled to be heard.

Alternatives to the framing of asylum seekers as engaging in deviant behaviour were limited due to the requirement that government and contractor employees on Nauru had to sign confidentiality agreements. In addition, the Coalition government was able to control the access to the processing camps on the island by anyone independent of the government through securing the support of the Nauru government to actualise this. Thus the conditions for the asylum seekers were rarely witnessed by independent sources and communicated to the outside world for some time. As noted earlier, aside from two journalists and an advocate who managed to access the camps in 2002 by posing as tourists, other journalists, advocates and lawyers were prevented from visiting the Nauru facility until 2004-2005. However, even then, the remote location of Nauru in relation to Australia meant that to travel there was very time consuming and expensive. The remoteness of Nauru was and remains an effective barrier to independent oversight of offshore processing.

\section{Detention on Nauru 2013}

There are similarities in the policies of the previous Coalition and current Labor governments in their focus on and efforts to persuade asylum seekers on Nauru to be compliant, and to hire other bodies to enable their policies. The Coalition government's offshore processing policy that held asylum seekers on Nauru last decade was enabled by the bodies who were recruited as apparatuses of security to actualise government policy. The physical conditions under which asylum seekers were held on Nauru, the initial refugee claims processing that denied natural justice to asylum seekers, and the constant pressures placed on those whose claims were initially rejected, were attempts to persuade asylum seekers into compliant behaviour that is, to voluntarily return to their own countries. In order to maximise support for its policy within the Australian electorate, the Coalition government required its contracted bodies and their employees to sign confidentiality agreements and, in the case of the Nauru government, to act to prevent Australians independent of the state visiting Nauru in the first three years.

\footnotetext{
${ }^{79}$ Pickering, Refugees and State Crime.
} 
Despite the despairing impact on the asylum seekers who were held on Nauru under the Coalition government's Pacific Solution, and the fact that the majority were found to be refugees or owed protection on other humanitarian grounds, Australia is once again responsible for the indefinite detention of asylum seekers on both Nauru and Manus Island under the Labor government's current policies. Reports from independent visitors to the detention camp on Nauru highlight that physical conditions and concerns about delays in claims processing mirror those in the camps a decade ago, and similar mental health concerns are also evident. ${ }^{80}$ With many of the recently erected buildings destroyed in the July 2013 fires in the camp, physical conditions are now likely to be harsher for asylum seekers on Nauru.

As with the Coalition government before it, the Labor government has contracted other bodies to enable its policy on Nauru. The Nauru government is again hosting the detention camp in return for receiving increased financial aid. Transfield Services is contracted to manage the operations of the detention camp, the International Health and Medical Services is providing healthcare facilities, the Salvation Army is responsible for providing case management support for those detained, and Wilson Security is managing the security of the camp. But this time the Australian government has gone further in contracting out its apparatuses of security. It has sought to completely outsource its responsibilities for considering the refugee status of the asylum seekers that have been transported to Nauru, by securing the agreement of the Nauru government to be responsible for the processing of all the refugee claims.

Just as the Coalition government required employees of its apparatuses of security to sign confidentiality agreements, so too has the Labor government. However, this time the confidentiality requirements of contracts signed by employees of the private operators contracted to enable Australian policy have been less effective in hiding the impacts of detention on Nauru from the Australian public. Secrecy of the conditions in the detention camp on Nauru has still been sought to a large extent by the Labor government, but there have been a number of media reports on conditions there that have drawn on the comments of some of the contracted employees on the island. ${ }^{81}$ In particular, 31 former and present employees of the Salvation Army who have been employed on Nauru and Manus Island over the past year

\footnotetext{
${ }^{80}$ Amnesty International, What We Found on Nauru; UNHCR, Mission to the Republic of Nauru 2012.

${ }^{81}$ See for example ABC, No Advantage.
} 
have released a public statement about their concerns for asylum seekers on Nauru. ${ }^{82}$ In addition, up until the recent fires, asylum seekers detained on Nauru had some access to means of communication with the outside world, such as limited access to the internet and telephones. ${ }^{83}$ The Labor government has also allowed a number of human rights organisations to visit the detention camp on Nauru and release public reports that raise their concerns, although Australia's Department of Immigration and Citizenship (DIAC) did not allow photographs to be taken. ${ }^{84}$ While the Nauru government has allowed journalists to visit the island, up until June 2013 DIAC has denied them access to the detention camp. ${ }^{85}$

However, the public reports of these independent witnesses as at the time of writing have yet to shift the views of enough Australians or Members of Parliament to alter Labor's offshore processing policy. The Labor government, and the Opposition, have consistently portrayed messages over the past few years that numbers of asylum seekers arriving to Australia by boat are cause for alarm, those engaged in people smuggling are "evil", and that asylum seekers must be deterred from embarking on boat journeys to Australia to avoid any further deaths at sea en route. Despite the leaks evident in the Labor government's attempts to control information from the Nauru camps, the greater access to communications technology by those detained on Nauru, and the public reports of others who have visited Nauru, the majority of public opinion in Australia on this issue is yet to shift. This suggests that the efforts of the Coalition government in the last decade in framing asylum seekers arriving by boat as deviant, its ability to actualise its Pacific Solution through its apparatuses of security, and its claims that its policies were responsible for the fall in numbers of boat arrivals by the middle of the last decade, continue to have an impact on public opinion in Australia.

The accounts of asylum seekers held on Nauru last decade highlight the despair that resulted from the governing strategies of the Coalition government. Reports from asylum seekers, some of those employed in the processing camp on Nauru, and independent visitors over the past nine months are now consistently portraying that despair is once again the result of Australia's offshore processing policy. Policy alternatives that do not seek to force asylum seekers into compliant behaviour that generates such despair are much needed.

\footnotetext{
${ }^{82}$ Past and Present Salvation Army Staff Members, The Nauru Riot: Staff Condemn Cruel and Degrading Conditions. A Statement by Past and Present Salvation Army Staff Members. 23 July 2013.

${ }^{83}$ N. Bryant, "Will new Nauru asylum centre deliver Pacific Solution?" BBC News Asia, 2013, available at: http://www.bbc.co.uk/news/world-asia-22953103 (last visited 29 July 2013).

${ }^{84}$ Amnesty International, What We Found on Nauru; UNHCR, UNHCR Mission to the Republic of Nauru.

${ }^{85}$ Bryant, "Will new Nauru asylum centre deliver Pacific Solution?"
} 